\title{
EHMTI-0235. Hemodialysis-related headache
}

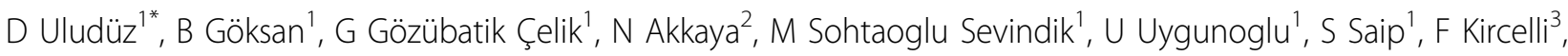 \\ A Sezen ${ }^{3}$, A Siva ${ }^{1}$ \\ From 4th European Headache and Migraine Trust International Congress: EHMTIC 2014 \\ Copenhagen, Denmark. 18-21 September 2014
}

\section{Background}

Hemodialysis (HD) increases expected lifetime of the patients minimizing the effects of neurological complications. However, dialysis may in itself, also have prejudicial effects on the nervous system. Headache (HDH) is the most common reported complaint among HD patients.

\section{Aim}

In the presented prospective study we aimed to further understand the HDH frequency and clinical characteristics in a large group of patients undergoing HD under standard dialysis programme with bicarbonate dialysate.

\section{Method}

A total of 494 patients were included. Patients undergoing HD sessions with no complaints of headache or any other neurological disorders were selected as control group. For HDH and control subjects arterial systolic and diastolic blood pressure, body weight, serum levels of BUN and creatinine were measured before and after one HD session.

\section{Results}

175 patients (35.42\%) were diagnosed with $\mathrm{HDH}$ and 275 patients were selected as controls. Headache was started with a mean of $2.90 \pm 0.72$ hours of the hemodialysis session. The pain was usually throbbing in bi-frontal region, the mean duration of headache was $6.1 \pm 7.7 \mathrm{~h}$, and VAS score was $5.63 \pm 2.02$.. The difference between pre- and post- dialysis values of BUN in patients with HDH was statistically significant,. Patients with HDH showed significantly higher mean systolic and diastolic blood pressure pre-dialysis values comparing with control group, whereas post-dialysis values did not differ between the two groups.

${ }^{1}$ Neurology Department, Istanbul UNiversity Cerrahpasa Medical Faculty, Istanbul, Turkey

Full list of author information is available at the end of the article

\section{Conclusion}

HDH may cause disability to the patient and changing dialysis parameters or methods can prevent the attacks and disability.

No conflict of interest.

\section{Authors' details \\ ${ }^{1}$ Neurology Department, Istanbul UNiversity Cerrahpasa Medical Faculty, Istanbul, Turkey. ${ }^{2}$ Cerrahpasa Medical Faculty, Istanbul UNiversity, Istanbul, Turkey. ${ }^{3}$ Department of Internal Medicine Nephrology Division, Istanbul University Cerrahpasa Medical Faculty, Istanbul, Turkey.}

Published: 18 September 2014

doi:10.1186/1129-2377-15-S1-C58

Cite this article as: Uludüz et al:: EHMTI-0235. Hemodialysis-related

headache. The Journal of Headache and Pain 2014 15(Suppl 1):C58.

\section{SpringerOpen $^{\circ}$}

C 2014 Uludüz et al; licensee Springer. This is an Open Access article distributed under the terms of the Creative Commons Attribution License (http://creativecommons.org/licenses/by/2.0), which permits unrestricted use, distribution, and reproduction in any medium, provided the original work is properly cited.
Submit your manuscript to a SpringerOpen ${ }^{\circ}$ journal and benefit from:

- Convenient online submission

- Rigorous peer review

- Immediate publication on acceptance

- Open access: articles freely available online

- High visibility within the field

Retaining the copyright to your article

Submit your next manuscript at $>$ springeropen.com 